Journal of

Innate Immunity
Editorial

J Innate Immun 2020;12:275-276

DOI: $10.1159 / 000509601$
Received: June 15, 2020

Accepted: June 15, 2020

Published online: June 25, 2020

\title{
The Road Not Taken: Commensal or Virulent Pathogen
}

Despite the ongoing COVID-19 pandemic, it is important to remember that bacterial pathogens remain a constant threat, not least in the light of resistance to antibiotics and an increasing number of immunocompromised individuals [1]. It is fascinating to observe that bacteria have evolved such different strategies, paving their way to success. Bacterial species being part of the human microbiota often promotes the well-being of the host through symbiosis, thereby securing their own longstanding ecological niche [2]. However, a disturbed composition of the microbiota may have a deleterious impact on, for example, energy metabolism, remote organ functions, and inflammatory diseases [3-6]. How could the strategies exerted by virulent bacterial pathogens result in evolutionary success, even though they harm and may even kill their host? The question is likely to have several complex answers, and opportunistic pathogens may hide in the shades in between. In this issue of the Journal of Innate Immunity, Siemens et al. [7] characterize a novel virulence factor of group B streptococci, i.e., a pigment toxin that caused the release of proinflammatory cytokines and induced blood clotting on the bacterial cell surface. In a clinical setting, the cytotoxic properties indeed play important roles in the clinical picture [8]. In another interesting article, Tsai et al. [9] show that when exposing macrophages to group B streptococci, sialic acid-binding immunoglobulin-type lectin receptors (Siglecs) modulate the response, where Siglec-14 had an enhancing effect whereas Siglec-5 reduced inflammasome activation and macrophage IL- $1 \beta$ release. The findings may have a bearing on modulation of the inflammatory response during severe infections. Liu et al. [10] found that activation of TLR3 results in IL-1 receptor antagonist expression through interferon regulatory factor 3 , demonstrating yet another intrinsic anti-inflammatory pathway. However, bacteria are also able to corrupt inflammasome activation as exemplified by the ubiquitination and degradation of pro-IL- $1 \beta$ by streptolysin O released by group A streptococci (Streptococcus pyogenes) [11]. These bacteria are highly pathogenic, causing a broad range of severe clinical conditions [12]. One important virulence factor of group A streptococci is the surface-associated M protein. Using cold atmospheric plasma, Persson et al. [13] investigated how these bacteria can be disarmed with regard to this virulence factor using this potentially important therapeutic approach.

The delicate balance between the virulence of bacterial pathogens and the degree of inflammatory response mounted by the host to clear the infection continues to challenge scientists and clinicians. As always, we hope that this collection of articles will be of great interest to the readership of the Journal of Innate Immunity.

Heiko Herwald, Lund Arne Egesten, Lund karger@karger.com

www.karger.com/jin

Karger"
(C) 2020 The Author(s)

Published by S. Karger AG, Basel

Karger
Open access

This is an Open Access article licensed under the Creative Commons Attribution-NonCommercial-4.0 International License (CC BY-NC) (http://www.karger.com/Services/OpenAccessLicense), applicable to the online version of the article only. Usage and distribution for commercial purposes requires written permission. 


\section{References}

1 Chatterjee A, Modarai M, Naylor NR, Boyd SE, Atun R, Barlow J, et al. Quantifying drivers of antibiotic resistance in humans: a systematic review. Lancet Infect Dis. 2018 Dec; 18(12):e368-78.

2 Reinhardt C. The Microbiota: A Microbial Ecosystem Built on Mutualism Prevails. J Innate Immun. 2019;11(5):391-2.

3 Esser D, Lange J, Marinos G, Sieber M, Best L, Prasse D, et al. Functions of the Microbiota for the Physiology of Animal Metaorganisms. J Innate Immun. 2019;11(5):393-404.

4 Grant M, Kilsgård O, Åkerman S, Klinge B, Demmer RT, Malmström J, et al. The Human Salivary Antimicrobial Peptide Profile according to the Oral Microbiota in Health, Periodontitis and Smoking. J Innate Immun. 2019;11(5):432-44.

5 Noor F, Kaysen A, Wilmes P, Schneider JG. The Gut Microbiota and Hematopoietic Stem Cell Transplantation: challenges and Potentials. J Innate Immun. 2019;11(5):405-15.
6 Endres K, Schäfer KH. Influence of Commensal Microbiota on the Enteric Nervous System and Its Role in Neurodegenerative Diseases. J Innate Immun. 2018;10(3):172-80.

7 Siemens N, Oehmcke-Hecht S, Hoßmann J, Skorka SB, Nijhuis RH, Ruppen C, et al. Prothrombotic and Proinflammatory Activities of the $\beta$-Hemolytic Group B Streptococcal Pigment. J Innate Immun. 2019 Nov;1-13.

8 Genga KR, Shimada T, Boyd JH, Walley KR, Russell JA. The Understanding and Management of Organism Toxicity in Septic Shock. J Innate Immun. 2018;10(5-6):502-14.

9 Tsai CM, Riestra AM, Ali SR, Fong JJ, Liu JZ, Hughes G, et al. Siglec-14 Enhances NLRP3Inflammasome Activation in Macrophages. J Innate Immun. 2019 Dec;1-11.
10 Liu Y, Mo CF, Luo XY, Li H, Guo HJ, Sun H et al. Activation of Toll-Like Receptor 3 Induces Interleukin-1 Receptor Antagonist Expression by Activating the Interferon Regulatory Factor 3. J Innate Immun. 2019 Dec;117.

11 Hancz D, Westerlund E, Valfridsson C, Aemero GM, Bastiat-Sempe B, Orning P, et al. Streptolysin $O$ Induces the Ubiquitination and Degradation of Pro-IL-1 $\beta$. J Innate Immun. 2019;11(6):457-68.

12 Laabei M, Ermert D. Catch Me if You Can: Streptococcus pyogenes Complement Evasion Strategies. J Innate Immun. 2019;11(1): 3-12.

13 Persson ST, Ekström S, Papareddy P, Herwald H. Cold Atmospheric Plasma Disarms M1 Protein, an Important Streptococcal Virulence Factor. J Innate Immun. 2019 Sep;1-14. DOI:10.1159/000502959. 